\title{
Eva KováŘovÁ*
}

\section{Territorial and Sectoral Distribution of the ODA Gross Disbursements Channelled Using Civil Society Organizations: Czechia Compared with Other Central European Countries}

\begin{abstract}
Civil society organizations represent important actors in delivery of development assistance. International community recognizes them not only as actors on their own, but also as the contractors of the official governmental programmes and projects. Their involvement in development policies of donor countries has been especially emphasized since the 1990s, and it is generally regarded as valuable in fulfilment of the 2030 Agenda for Sustainable Development. Governments of the Central European Countries also cooperate with civil society organizations in development policies, and use them inter alia as the channels for aid delivery. However, the level in which governments use their services in delivery of the Official Development Assistance differs. Therefore, the aim of this paper is to identify and evaluate territorial and sectoral distribution of the ODA gross disbursements of Czechia channelled using civil society organizations, and to compare this distribution with the ones found in Hungary, Poland and Slovakia. Through civil society organizations Czechia has allocated nearly $1 / 4$ of its total volume of ODA gross disbursements related to individual programmes and projects during the period between 2014 and 2018. However, the Hungarian government cooperated with civil society organizations marginally, and their participation reached a maximum level of $6 \%$ in 2018. Civil society organizations, participating in development policies of the Central European
\end{abstract}

* VŠB - Technical University of Ostrava, Faculty of Economics, Department of Public Economics. Address: 17. listopadu 2172/15, 70800 Ostrava-Poruba, Czech Republic. eva.kovarova@vsb.cz; ORCID: 0000-0002-1548-6889. 
Countries, were involved mainly in the programmes and projects concerning social infrastructure and services, which complies with their traditional and most common roles.

Key words: civil society organizations, development policy, gross disbursement, official development assistance, sustainable development.

JEL Classification: F35, F43, F63, Q01.

\section{Introduction}

Official Development Assistance (ODA) represents one of the most important external financing resources that can help low- and middle-income countries with the fulfilment of the 2030 Agenda for Sustainable Development. Organisation for Economic Co-operation and Development considers ODA the assistance provided by official agencies, including state and local governments, or by their executive agencies on concessional terms, and administrated with the aim to promote economic development and welfare in poorer countries (OECD, 2020a). Donor countries deliver their assistance using various channels, while civil society organizations (CSOs) are considered to be of growing importance.

In the field of ODA delivery, CSOs usually serve as the contractors to official governmental programmes, and they deliver development assistance via realization of the bilateral projects financed from the public sources of donor countries. However, they also pursue their own projects, that can be co-financed from public sources. Their involvement in governmental development policies has been internationally recognized since the late 1980s. The New European Consensus on Development, which introduces common principles of the European Union's and its Member States' development policies, considers civil society organizations to be "instrumental partners in reaching the most vulnerable and marginalised people"; and evaluates their participation as valuable, so that it "encourages all parts of society to actively engage" (European Council, 2017: 6; 35). The 2030 Agenda for Sustainable Development requires encouragement and promotion of the "effective public, public-private and civil society partnership" for achieving the Agenda's goals (United Nations, 2015: paragraphs 17.17). Global Partnership for Effective Development Cooperation (2020: 9) states that civil society organizations are "development actors in their own right" and sees them "at the forefront of development efforts".

The Central European Countries - Czechia, Hungary, Slovakia and Poland (further referred to as "CEC") belong to the official donor community, being members 
of the Development Assistance Committee of the Organisation for Economic Co-operation and Development (OECD DAC). As the EU Member States, the CEC adopt and implement their own development policies as well as participate in the EU development policy, as it is defined in the Treaty on the Functioning of the European Union (2007): "In the areas of development cooperation and humanitarian aid, the Union shall have competence to carry out activities and conduct a common policy; however, the exercise of that competence shall not result in Member States being prevented from exercising theirs" (Article 4, paragraph 4); while the EU and Member States' policies "complement and reinforce each other" (Article 208).

The CEC laid the legal basis of their development policies using their national legislation, and they specify their thematic and territorial priorities with regularly issued concepts, particularly strategies of development cooperation. Their priorities should comply with the international and EU commitments, particularly regarding the volume of ODA and its overall objectives. Since the adoption of the 2030 Agenda for Sustainable Development in 2015, donor countries are asked to contribute to the fulfilment of the Agenda's priorities using their development policies, which was reflected at the EU level by the European Consensus on Development in 2017. The Consensus declares that the EU and its Member States will implement the 2030 Agenda in "partnership with all developing countries", and emphasizes the necessity to respond to "current global challenges and opportunities" in the light of this Agenda (European Council, 2017: 2-3).

The CEC cooperate with CSOs in the implementation and realisation of their development policies, using them as channels for ODA delivery. Each country can choose the extent in which its CSOs are involved in the development policy, and thematic areas and countries where CSOs can participate in a delivery of the aid. Therefore, it can be expected that some differences exist among the CEC. Therefore, the aim of the paper is to identify and evaluate territorial and sectoral distribution of the ODA gross disbursements of Czechia channelled using civil society organizations, and to compare this distribution with the ones identified for three other Central European Countries (Hungary, Poland, Slovakia). The main emphasis is placed on Czechia, because Czechia launched its official governmental development policy as the first Post-communist Central European Country in the mid-1990s.

The analysis focuses on the period between 2014 and 2018, the data for which was extracted from the OECD. Stat in October 2020. Presented results should be considered partial results of a wider research dealing with the ODA delivered by countries that had accessed the EU after the year 2003. Research is motivated by the claim presented by Lewis and Kanji (2009) who wrote that the research literature on 
development non-governmental organizations remained underdeveloped. Especially in Czech research space, no serious studies dealing with the topic of CSOs in the context of ODA delivery were published in recent years.

\section{Theoretical Background of the Analysis}

Civil society is generally understood as the third sector of the economy, existing alongside the government and business sector. Therefore, civil society organizations (CSOs) are characterized as private, non-profit, self-governing, voluntarily constituted and supported organizations (Ott and Valero, 2018). With respect to the EU terminology, "civil society organisations are independent actors, organised on a notfor-profit and voluntary basis, and active in different fields, such as poverty reduction, emergency aid, human rights, environment etc." (European Commission, 2020). This understanding is close to the understanding of non-governmental organizations (NGOs) introduced by Clarke (1998: 36) who describes NGOs as "the private, nonprofit, professional organizations with a legal character, concerned with public welfare goals." However, non-governmental organizations should be "recognised as only one, albeit important, actor in civil society" (Banks and Hulme, 2012: 2). Besides the nongovernmental organizations, civil society consists of charities, community groups and associations, professional associations, trade unions, social movements and advocacy groups.

The origin of the term NGO refers to the United Nations Charter, adopted in 1945, which speaks in its article 71 about consultations of the United Nations Economic and Social Council with the non-governmental organizations (United Nations, 2020). Soon after the introduction of the Charter the term NGO was adopted for common use by organizations of such type (Willetts, 2011). Today, non-governmental organizations are generally considered, in the context of development cooperation, as the organizations constituted in their home countries and organized to work across national borders (Brown et al., 2000), or to operate outside their home countries (Ott and Valero, 2018). The original term Non-Governmental Organization is sometimes extended to emphasize the transnationality or the focus on topics concerning development, the terms international non-governmental organization (Brown et al., 2000; Ott and Valero, 2018), or non-governmental development organization (Lewis, 2001; Horký, 2011; Banks and Hulme, 2012) are the ones used most commonly. 
The gradual involvement of the CSOs/NGOs in development policies is being observed since the late 1980s (Lewis and Kanji, 2009), while until the late 1970s CSOs/NGOs were little-recognised for the implementation of development projects (Banks and Hulme, 2012). The rise in their numbers and international influence, and thus participation in development cooperation, was affected by neoliberalism and expanding globalization in the late 1980s and 1990s. However, this rise also had some pragmatic reasons, such as technological progress, and was affected by the end of the Cold War in positive terms (Ott and Valero, 2018). In the 1990s, $\mathrm{CSO} / \mathrm{NGO}$ were regarded as development actors bringing new solutions to longlasting development problems characterized with inefficient inter-governments aid and ineffective development projects (Lewis, 2001). Emphasis placed on principles of good governance, partnership, recipient countries' ownership, transparency and accountability opened space for further cooperation with CSOs/NGOs in development affairs in the 2000s. Today, CSOs/NGOs are considered to be important actors in the development field (Lewis and Kanji, 2009); an integral part of the development aid industry (Lewis, 2001); and channels for significant volumes of ODA (Clarke, 1998).

CSOs/NGOs especially work to deliver various services to the people in need (Lewis and Kanji, 2009), which is considered their traditional and most common role (Brown et al., 2000). They provide services in many fields, from livelihood interventions, health and education services, to more specific areas such as democracy building, defence of human rights or conflict resolutions (Lewis and Kanji, 2009). They are considered to be innovative in programmes aimed at reducing infant and maternal mortality, promoting health care and education, providing the basic services of water supply and sanitation (Helmich, 1999) and delivering services related to social development (Smillie, 1999). However, they also organize public advocacy and public campaigns for change (Lewis and Kanji, 2009), or build public support for governmental development policies in donor countries (Smillie, 1999). In development aid delivery they usually serve as the contractors to official governmental programmes of development assistance (Helmich, 1999), while their primary function is seen in transferring (channelling) resources from donor countries to the recipient ones. Positives and negatives connected with the CSOs/NGO participation in delivery of the development aid are shortly summarized in Table 1. 
Table 1: Positives and negatives of the CSOs participations in development cooperation

\begin{tabular}{|l|l|}
\hline \multicolumn{1}{|c|}{ Positives } & \multicolumn{1}{c|}{ Negatives } \\
\hline $\begin{array}{l}\text { Alternative and more flexible funding channel } \\
\text { with lower costs (Lewis and Kanji, 2009) }\end{array}$ & $\begin{array}{l}\text { Undermining centrality of the state receiving } \\
\text { Promotion of local participation }\end{array}$ \\
$\begin{array}{l}\text { (Lewis and Kanji, 2009) } \\
\text { Organization and motivation for sustainable } \\
\text { community self-efforts (Smillie, 1999) }\end{array}$ & $\begin{array}{l}\text { Spreading neo-liberal policy orthodoxies } \\
\text { (Lewis, 2001) }\end{array}$ \\
Innovations in programmes concerning basic hijacking of their activities by elite \\
human needs (Helmich, 1999) & $\begin{array}{l}\text { groups of professional activists or interest groups } \\
\text { (Nanz and Steffek, 2004) }\end{array}$ \\
& $\begin{array}{l}\text { Quiet suspect legitimacy (Brown et al., 2000) } \\
\text { Questionable effectiveness, accountability, } \\
\text { and legitimacy (Tortajada, 2016) }\end{array}$ \\
\hline
\end{tabular}

Source: Own literature review

Legitimacy, transparency and accountability of CSOs/NGOs are the most questioned affairs. Therefore, international community aims to enhance their accountability, which is also reflected in the outcomes of so-called High-level Forums on Aid Effectiveness (held in Rome in 2002; Paris 2005, Accra 2008, Busan 2011). In 2011 the fourth, and last, Forum launched so-called Busan Partnership Agreement, that recognized the importance of the CSOs role in development cooperation, while the Agreement's signatories committed themselves to (a) enable CSOs to exercise their roles as independent development actors; (b) encourage CSOs to implement practices that strengthen their accountability and that contribute to development aid effectiveness. Transparency and accountability are objectives of CSOs in themselves, as well as principles of the effectiveness of their aid, as declared by the Open Forum for CSO Development Effectiveness with the Istanbul CSOs Development Effectiveness Principles launched in 2010 (CSO Partnership, 2020).

\section{Formulation of the Research Objective and Structure of the Analysis}

The aim of the paper is to identify and evaluate territorial and sectoral distribution of the ODA gross disbursements of Czechia channelled using civil society organizations, and to compare this distribution with the ones found in the three other Central European Countries (Hungary, Poland and Slovakia). The analysis is focused on the period between 2014 and 2018 due to the absence of data concerning longer periods, and it concerns the Central European Countries since they are subject to 
the same international and European Union commitments concerning the Official Development Assistance.

The research, results of which are presented further, was based on a review of relevant scientific literature, an analysis of the CEC national strategies specifying priorities of their development policies, as well as on quantitative analysis of secondary statistical data quantifying the involvement of CSOs in ODA delivery of Central European Countries. The analysed statistical data was extracted from the OECD.Stat in October 2020, from a database called Creditor Reporting System Aid Activity Database (CRS), which provides basic data collected on individual projects and programmes of the donor countries. This Database reports ODA flows of the type called gross disbursements, a disbursement being understood as "the placement of resources at the disposal of a recipient country or agency, or in the case of internal development-related expenditures, the outlay of funds by the official sector" (OECD. Stat, 2020).

Organisation for Economic Co-operation and Development (2020c) uses terms Non-Governmental Organisations and Civil Society Organizations as synonyms for organizations constituted as non-profit entities organized on a local, national or international level, and without significant government-controlled participation or representation. The OECD reports gross disbursements of aid with respect to different channels of delivery, the one related to CSOs being called NGOs \& civil society. To show that assistance reported by the CEC to the OECD Credit Reporting System could be delivered using various actors of a civil society, modified acronym $\mathrm{CS}(\mathrm{O})$ is used to introduce results of the statistical analysis.

To meet the aim of the paper, statistical analysis of the Czech ODA gross disbursements related to individual programmes and projects is divided into several parts:

(1) Involvement of the CSOs in development cooperation is evaluated by calculating the percentage shares of the volume of ODA gross disbursements delivered using the CSO channel in total volume of gross disbursements reported to the CRS. Attention is given to the percentage shares calculated for all developing countries and for all developing regions, respecting their OECD definition.

(2) Distribution of the ODA gross disbursements delivered using the CSO channel among main developing regions is evaluated by calculating regions' percentage shares in the total volume of gross disbursements delivered using the CSO channel to all developing countries, with respect to the CRS database.

(3) Distribution of the ODA gross disbursements delivered using the CSO channel among main thematic sectors is evaluated by calculating sectors' percentage 
shares in the total volume of gross disbursements delivered by CSOs to all sectors, with respect to the CRS database.

The results for Czechia are then graphically compared with the ones identified for Hungary, Poland and Slovakia. Research follows two hypotheses: (1) CSOs are internationally recognized as important actors of the development aid industry, and thus CSOs will participate in development policies of the CEC too; (2) CSOs are generally expected to serve as providers of basic services related to social development, and thus CSOs will act their traditional role also within the frames of the CEC development policies too.

\section{Results and Findings}

Czechia introduced its official foreign development policy as the first Postcommunist Central European Country in the mid-1990s. However, the first concept of development cooperation was launched for the period between 2002 and 2007. "Reduction of poverty through the economic and social development" was stated as its main objective (Czechia, Ministry of Foreign Affairs, 2001: 3). CSOs were regarded as the actors in public discussion on foreign development policy (Czechia, Ministry of Foreign Affairs, 2001). In 2010, Czechia adopted its first national Act on Development Cooperation and Humanitarian Aid, and launched a second strategy of development policy for the period 2010-2017. This strategy recognized non-governmental organizations among the key players in development cooperation. Thematically, cooperation should have been focused on environment, agriculture, social and economic development, promotion of democracy, human rights and social transformation (Czechia, Ministry of Foreign Affairs, 2010).

Current development cooperation strategy has been adopted for the period of 2018 to 2030, and aims to "create strategic partnerships in development cooperation between the public, civil and academic sectors" as involvement of the non-governmental sector is seen in the implementation of the development cooperation (Czechia, Ministry of Foreign Affairs, 2017: 5). Main territorial priority has been assigned to the Eastern European Countries, as well as to some African and Asian countries. Main thematic priorities are defined in relation to the 2030 Agenda for Sustainable Development, and include good democratic governance, sustainable management of natural resources, economic transformation and growth, agriculture, rural development or inclusive social development (Czechia, Ministry of Foreign Affairs, 2017). Concepts/strategies 
of development cooperation were formulated by the Czech Ministry of Foreign Affairs, and the Czech Development Agency had been set as the administrative unit responsible for the implementation and formulation of development cooperation programmes. The Agency offers tenders and grants through which actors from non-governmental sectors (both business and civil) become the contractors to governmental ODA projects.

Comparable which Czechia, the other CEC also define their development policies using their national legal acts (Hungarian has been in force since 2014, Polish since 2011 and Slovakian since 2015), and specify their territorial and sectoral priorities with regularly issued strategic documents. Currently applied documents are introduced in Table 2, where the role of CSOs in development policy is also explained with respect to these documents.

Table 2: Overview of other CEC strategies and the context of CSO participation

\begin{tabular}{|l|l|l|}
\hline Country & \multicolumn{1}{|c|}{ Actual Strategy } & \multicolumn{1}{|c|}{ Role of CS(Os) with respect to Strategy } \\
\hline Hungary & $\begin{array}{l}\text { Concept for } \\
\text { International } \\
\text { Humanitarian Aid } \\
\text { of Hungary } \\
\text { 2014-2020 }\end{array}$ & $\begin{array}{l}\text { Civil society organizations "play a pivotal role in the implementation } \\
\text { of the development cooperation", alongside to public administrations } \\
\text { (p. 4), and they are "key partners of the policy-makers in the } \\
\text { planning, evaluation and awareness raising process of the Hungarian } \\
\text { development cooperation" (p. 13). } \\
\text { However, Hungary seeks how "to increase the involvement of CSOs } \\
\text { in the planning and implementing of the development projects" (p. 8). }\end{array}$ \\
\hline Poland & $\begin{array}{l}\text { Multiannual } \\
\text { Development } \\
\text { Cooperation } \\
\text { Programme } \\
\text { 2016-2020 }\end{array}$ & $\begin{array}{l}\text { Civil society is recognized as one of the "stakeholders of Polish } \\
\text { development cooperation" (p. 3). Then, non-governmental } \\
\text { organizations are specified as the channel for allocation of } \\
\text { development cooperation finance, when they are assigned to be the } \\
\text { "first and foremost conducted" channel for the aid allocation (p. 40). }\end{array}$ \\
\hline Slovakia & $\begin{array}{l}\text { Medium-term } \\
\text { Strategy for } \\
\text { Development } \\
\text { Cooperation of the } \\
\text { Slovak Republic } \\
\text { for 2019-2023 }\end{array}$ & $\begin{array}{l}\text { Strategy recognizes the move "from state foreign assistance to a more } \\
\text { inclusive role for everybody", including also the civil society, when } \\
\text { explaining that "non-governmental organizations in particular are } \\
\text { key partners in the development area" (p. 3). } \\
\text { Cooperation with the civil society is considered to be structured } \\
\text { efficiently (p. 5), and the role of civil society in "implementing } \\
\text { development cooperation projects in partner countries is crucial" } \\
\text { (p. 40). }\end{array}$ \\
\hline
\end{tabular}

Source: Hungary, Ministry of Foreign Affairs and Trade (2020); SlovakAid (2020); Website of the Republic Poland gov.pl (2020), own documents' review 


\section{Territorial Distribution of the ODA Gross Disbursements Channelled Using the $\mathrm{CS}(\mathrm{O})$}

Czechia and other CEC do not meet the international and EU commitments concerning the volume of ODA. Between the years 2004 and 2018 the volume of Czech ODA related to GNI did not exceed $0.15 \%$, while the international target defined by the United Nations is $0.70 \%$; and the EU one, specified separately for the Member States accessing the EU after 2003, is 0.33\%. However, between the years 2014 and 2018, Czech gross disbursements reported for individual ODA programmes were increased by 36,471 mil. USD in absolute terms, respectively by $57.26 \%$. In 2014 , the highest percentage of such aid flows was allocated to Europe (31.3\%), followed by Asia (28.1\%). In the following years the importance of Europe and Asia as the aid recipient regions started to decline gradually. In 2018, only $25.7 \%$ of the ODA gross disbursements related to individual programmes was allocated in Europe, resp.19.5\% in Asia. However, this finding has to be considered in relation to the growth of aid reported within the unspecified category (see Table 3 ).

Table 3: Distribution of the Czech ODA gross disbursements among developing regions using all channels

\begin{tabular}{|l|r|r|r|r|r|}
\hline Million USD, constant prices 2018 & \multicolumn{1}{|c|}{2014} & \multicolumn{1}{c|}{2015} & \multicolumn{1}{c|}{2016} & \multicolumn{1}{c|}{2017} & \multicolumn{1}{c|}{2018} \\
\hline Developing countries & 63,696 & 83,568 & 83,512 & 88,885 & 100,167 \\
\hline Europe & 19,955 & 24,465 & 22,184 & 20,469 & 25,737 \\
\hline Africa & 6,916 & 8,025 & 7,397 & 11,025 & 12,034 \\
\hline America & 0,805 & 0,823 & 0,932 & 1,134 & 1,317 \\
\hline Asia & 17,876 & 27,013 & 26,634 & 24,938 & 19,545 \\
\hline Oceania & 0 & 0 & 0 & 0,026 & 0 \\
\hline Unspecified & 18,143 & 23,243 & 26,364 & 31,294 & 41,535 \\
\hline
\end{tabular}

Source: OECD.Stat, database Creditor Reporting System (2020)

During the period between 2014 and 2018, CS(O) channel was used to deliver about $1 / 4$ of all gross disbursements allocated through individual ODA programmes to all developing countries (see Table 4). This channel was mostly used to deliver ODA to poorer developing regions (Africa, Asia). The importance of the CS(O) channel was enhanced for Asia because the participation of CS(O) in aid delivery grew by $33 \%$, from $19.7 \%$ (year 2015) to $52.5 \%$ (year 2018). 
Table 4: Share of the CS $(O)$ channel on all channels used for the Czech ODA gross disbursements delivery

\begin{tabular}{|l|r|r|r|c|c|}
\hline \multicolumn{1}{|c|}{ In percent } & \multicolumn{1}{c|}{2014} & \multicolumn{1}{c|}{2015} & \multicolumn{1}{c|}{2016} & \multicolumn{1}{c|}{2017} & \multicolumn{1}{c|}{2018} \\
\hline Developing countries & 24,652 & 21,632 & 24,333 & 21,814 & 23,070 \\
\hline Europe & 28,468 & 34,396 & 29,489 & 26,325 & 23,087 \\
\hline Africa & 51,586 & 38,327 & 51,698 & 36,697 & 45,530 \\
\hline America & 32,639 & 39,708 & 21,489 & 37,475 & 37,001 \\
\hline Asia & 29,837 & 19,648 & 33,071 & 34,692 & 52,523 \\
\hline Oceania & 0 & 0 & 0 & 0 & 0 \\
\hline Unspecified & 4,725 & 4,099 & 3,591 & 2,762 & 2,252 \\
\hline
\end{tabular}

Source: OECD.Stat, database Creditor Reporting System (2020), own data processing

Distribution of total gross disbursements of ODA among main developing regions using the CS(O) channel changed significantly during the period of 2014-2018. In 2014, one third of such ODA allocations was delivered to Europe (36.2\%) and to Asia (34\%), but allocation to Europe has declined since 2015 in favour of Asia (see Table 5).

Table 5: Territorial distribution of the Czech ODA gross disbursements channelled using the $\mathrm{CS}(\mathrm{O})$

\begin{tabular}{|l|r|r|r|r|r|}
\hline \multicolumn{1}{|c|}{ In percent } & \multicolumn{1}{c|}{2014} & \multicolumn{1}{c|}{2015} & \multicolumn{1}{c|}{2016} & \multicolumn{1}{c|}{2017} & 2018 \\
\hline Europe & 36,178 & 46,549 & 32,192 & 27,792 & 25,713 \\
\hline Africa & 22,721 & 17,014 & 18,819 & 20,866 & 23,709 \\
\hline America & 1,673 & 1,807 & 0,985 & 2,191 & 2,108 \\
\hline Asia & 33,968 & 29,359 & 43,344 & 44,620 & 44,423 \\
\hline Oceania & 0 & 0 & 0 & 0 & 0,090 \\
\hline
\end{tabular}

Source: OECD.Stat, database Creditor Reporting System (2020), own data processing

It seems that Czechia relies on $\mathrm{CS}(\mathrm{O})$ participation in development programmes and projects implemented especially in Asia, because that is where $\mathrm{CS}(\mathrm{O})$ delivered $52.5 \%$ of the ODA gross disbursements in 2018; and $44.4 \%$ of ODA gross disbursements related to individual programmes and delivered using the CS $(\mathrm{O})$ channel was allocated to Asia as well.

All CEC increased their gross disbursments of ODA allocated through individual projects and programmes betwen the years 2014 and 2018, while the highest spending in absolute terms was recorded by Poland (see Figure 1). 
Figure 1: CEC ODA gross dibursments allocated to all developing regions (in mil. USD)

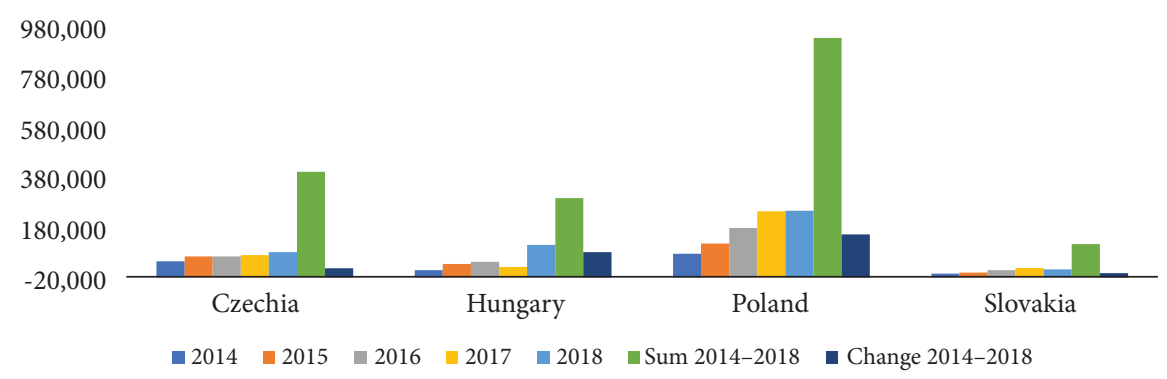

Source: OECD.Stat, database Creditor Reporting System (2020), own data processing

All CEC countries delivered ODA using the CS(O) channel, which confirms the first research hypothesis. However, the involvement of $\mathrm{CS}(\mathrm{O})$ in aid delivery significantly differs among CEC. While Slovakia use of CS(O) channel was comparable with Czechia, Poland involved CS(O) in aid delivery on significantly lower level, and the lowest participation of $\mathrm{CS}(\mathrm{O})$ was reported by Hungary, which had to use CSO channel only in a minimal amount of cases (see Figure 2). In 2014, the share of $\mathrm{CS}(\mathrm{O})$ channel in total volume of Hungarian ODA gross disbursements allocated to all developing countries accounted for only $0.14 \%$, while the maximal level of $6.02 \%$ was reached in 2018.

Figure 2: CEC ODA gross dibursments allocated to all developing regions using the $\operatorname{CS}(\mathrm{O})$ channel (in percent)

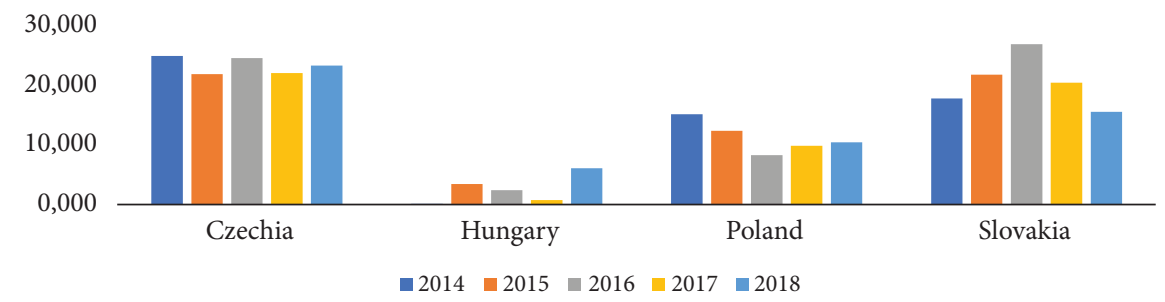

Source: OECD.Stat, database Creditor Reporting System (2020), own data processing

CS(O) were used by all CEC to channel aid allocated through individual projects and programmes to all developing regions during the whole period of 2014 to 2018. However, regions with the highest CS $(\mathrm{O})$ participation differ among the CEC. Slovakia spent the main part of the total volume of ODA gross disbursements delivered using $\mathrm{CS}(\mathrm{O})$ channel in Africa, Poland and Hungary in Europe, and Czechia in Asia (see Figure 3). 
Figure 3: CEC distribution of the ODA gross disbarments among developing regions channelled using the $\mathrm{CS}(\mathrm{O})$ (in percent)

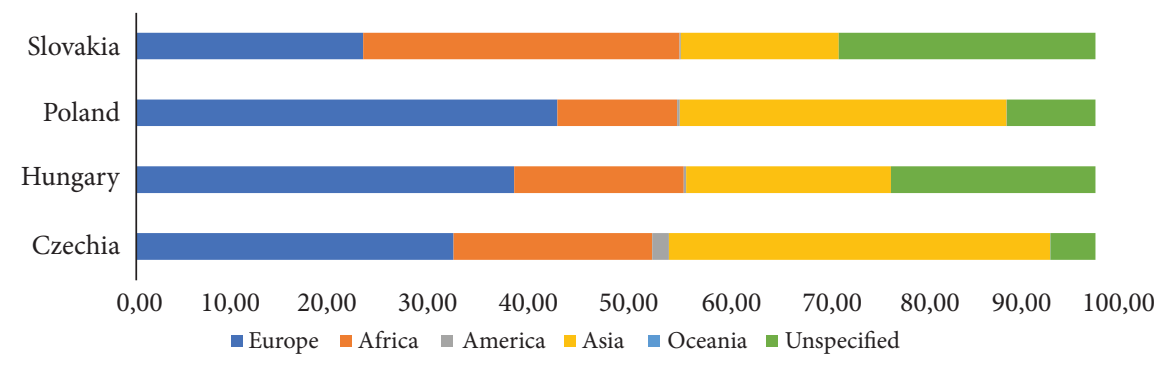

Source: OECD.Stat, database Creditor Reporting System (2020), own data processing

\section{Sectoral Distribution of the ODA Gross Disbursements Channelled Using the CS(O)}

In the Creditor Reporting System OECD recognizes eight sectors for the ODA gross disbursements allocation through individual programmes and projects. In this paper attention is further paid to four sectors, including (1) social infrastructure and services; (2) economic infrastructure and services; (3) production sectors; (4) multisector/cross-cutting. The other sectors are not viewed as sectors with direct link to sustainable development (sectors of the commodity aid, humanitarian aid and refugees in donor countries) or they represent links to past heritage (sector of the action related to debt).

Distribution of the ODA spent through individual programmes and projects among thematic sectors is especially influenced by the CEC priorities defined in their strategic documents. Czechia, respectively the Czech Ministry of Foreign Affairs and Czech Development Agency, opens space for CS(O) participation in defined themes through regularly announced grants and tenders, especially in so-called soft projects related to basic services. Therefore, the highest participation of CS(O) was reported for individual programmes and projects executed within the sector of social infrastructure services (see Table 6). 
Table 6: Sectoral distribution of the Czech ODA gross disbursements channelled using the $\operatorname{CS}(\mathrm{O})$

\begin{tabular}{|l|c|c|c|c|c|}
\hline \multicolumn{1}{|c|}{ In percent } & 2014 & 2015 & 2016 & 2017 & 2018 \\
\hline Social infrastructure and services & 54,396 & 58,123 & 57,597 & 51,226 & 42,621 \\
\hline $\begin{array}{l}\text { Economic infrastructure } \\
\text { and services }\end{array}$ & 2,976 & 2,061 & 2,015 & 2,986 & 1,672 \\
\hline Production sectors & 11,239 & 11,666 & 9,000 & 8,998 & 9,812 \\
\hline Multi-sector & 2,042 & 0,308 & 1,460 & 1,195 & 4,102 \\
\hline
\end{tabular}

Source: OECD.Stat, database Creditor Reporting System (2020), own data processing

The sector of social services and infrastructure includes, respecting the OECD methodology, such sub-sectors as education, health, population policies, water supply and sanitation, government and civil society. Those are the sectors where a higher involvement of $\mathrm{CS}(\mathrm{O})$ in aid delivery is generally expected. Other CEC cooperated with $\mathrm{CS}(\mathrm{O})$ especially in the sector of social infrastructure and delivery(see Figure 4).

Figure 4: CEC distribution of the volume of ODA gross disbarments among sectors channelled using the $\mathrm{CS}(\mathrm{O})$ (in percent)

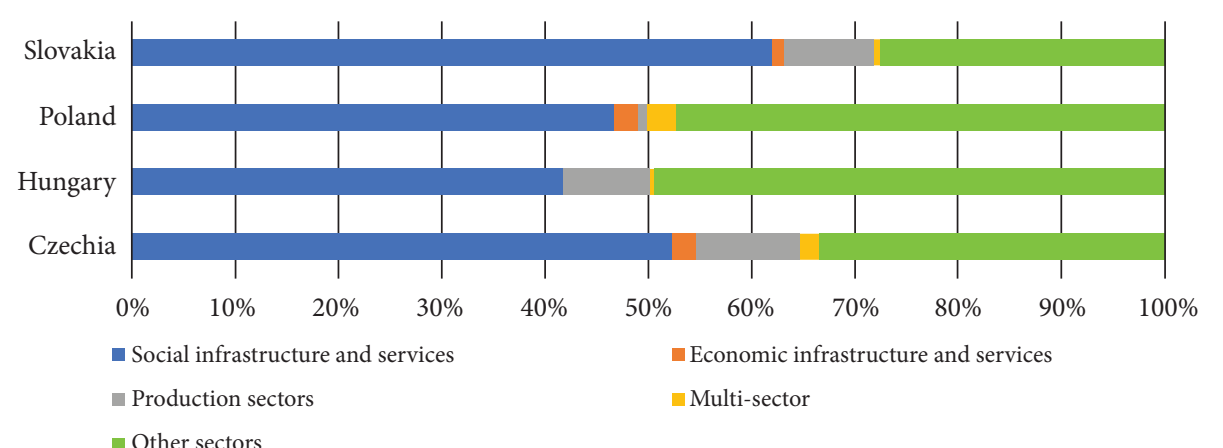

Source: OECD.Stat, database Creditor Reporting System of the OECD (2020), own data processing

Between 2014 and 2018 Czechia used the CS(O) channel to allocate $52.31 \%$ of its total ODA gross disbursements related to individual programmes and projects in the sector of social infrastructure and services, while for Slovakia it amounted to $62.6 \%$. Polish spending was lower only by 5 p.p. and Hungary reported sectoral distribution only for the years 2015-2018, but again the main part (41.78\%) of its gross disbursements was allocated in favour of the social infrastructure and services sector. These findings confirm second research hypothesis concerning the involvement of $\mathrm{CS}(\mathrm{O})$ in the delivery of basic services related to social development. 


\section{Conclusions}

Civil society organizations have been important actors of the development aid industry especially since the 1990s, when their involvement has been emphasized by the 2030 Agenda for Sustainable Development adopted by the United Nations in 2015. Organisation for Economic Co-operation and Development, which Development Assistance Committee gathers official ODA donor countries, explains that the Agenda clearly calls for the CSOs "engagement in implementation of the Sustainable Development Goals", when the OECD recognizes CSOs to be the providers of services in development and humanitarian situations that can also "influence policies through dialogue and advocacy, promote and protect human rights and democratisation" (OECD, 2020d: 26; 11). Participation of the CSOs in aid delivery is generally seen as valuable and fruitful, since they have the ability to reach the most marginalized people living in poverty or facing inequality. Therefore, their participation is a promise that nobody will be left behind, which is the promise declared by the International Community in the Preamble of the 2030 Agenda for Sustainable Development (United Nations, 2015).

The Central European Countries, including Czechia, Hungary, Poland and Slovakia, belong to the donor countries and active members of the OECD DAC. However, their development cooperation policies, built since their accession to the European Union in complementarity to the EU one, are still "new" for them and they show some flaws. However, CEC use the opportunities offered them by the European and global development aid industry and emphasize the principles of global governance. Although their civil societies have been not well-developed yet, their participation in delivery of the Official Development Assistance is expected and required with the countries' national strategies of development cooperation. They are especially involved as the contractors to official governmental programmes and projects.

During the period between the years 2014 and 2018 the highest involvement of civil society organizations in aid delivered through individual programmes and projects was found in Czechia and Slovakia, which were followed by Poland. Hungary, however, did not involve the CSOs in its development policy sufficiently, and in two years the volume of aid delivered using the CSO channel did not exceed 1\% of total gross disbursements of aid. Territorial distribution of the ODA gross disbursements channelled using the CSOs was rather fragmented for all CEC. However, the analysis showed that Europe, which is not a typical developing region, received important part 
of such ODA flows of all CEC. It confirms strategic and political orientation of the Central European Countries in their development policies, as well as willingness to share their own experience with economic and political transformation with other European countries. When the sectoral distribution is considered, the main part of ODA channelled using the CSOs was allocated by the CEC to the sector of social infrastructure and services, which is consistent with general expectations.

To conclude the paper, it is necessary to add that no Central European Country meets the international and European targets concerning the volume of ODA, defined by the ratio ODA/GNI. Net ODA flows recorded by the OECD for individual Central European Country did not exceed level of $0.15 \%$, while the EU commits the CEC to allocate at least $0.33 \%$ of their GNI, and the United Nations long-standing target is defined at the level of $0.7 \%$. Now, in the time of COVID-19, it will be particularly difficult for the Central European Countries to sustain or increase their ODA flows due to increased domestic public spending, and thus probably lower political and public willingness to help other, poorer countries, which are also affected by COVID-19 in negative terms.

\section{References}

Banks N., Hulme D. 2012. The role of NGOs and civil society in development and poverty reduction. Brooks World Poverty Institute Working Paper 171, University of Manchester.

Brown L. D., Khagram S., Moore M. H., Frumkin P. 2000. Globalization, NGOs and MultiSectoral Relations. The Hauser Center for Nonprofit Organizations and The Kennedy School of Government Harvard University, Working Paper \#1.

Clarke G. 1998. „Non-governmental organizations (NGOs) and Politics in Developing World”. Political Studies, Vol. XLVI: 36-52.

CSO Partnership for Development Effectiveness. 2020. "Istanbul CSO Development Effectiveness Principles”. https://csopartnership.org/resource/istanbul-principles-for-cso-developmenteffectiveness/, [accessed on: 19.10.2020].

Czechia. Ministry of Foreign Affairs. 2017. "Development Cooperation Strategy of the Czech Republic 2018-2030“. http://www.czechaid.cz/wp-content/uploads/2016/09/CZ_ Development_Cooperation_Strategy_2018_2030.pdf, [accessed on: 19.10.2020].

Czechia. Ministry of Foreign Affairs. 2010. "The Development Cooperation Strategy of the Czech Republic 2010-2017”. http://www.czechaid.cz/wp-content/uploads/2016/09/Development_ Cooperation_Strategy_2010_2017.pdf, [accessed on: 19.10.2020]. 
Czechia. Ministry of Foreign Affairs. 2001. "Koncepce zahraniční rozvojové pomoci České republiky na období let 2002-2007”. https://www.mzv.cz/public/7/36/4a/18290_14945_zrp_ cz.pdf, [accessed on: 19.10.2020].

European Commission. 2020. "Civil Society”. https:/ec.europa.eu/international-partnerships/ our-partners/civil-society_en, [accessed on: 19.10.2020].

European Council, Council of the European Union. 2017. "The New European Consensus on Development". https://www.consilium.europa.eu/media/24004/european-consensus-ondevelopment-2-june-2017-clean_final.pdf, [accessed on: 19.10.2020].

Global Partnership for Effective Development Cooperation. 2020. "How We Partner Together for Sustainable Development”. https://www.effectivecooperation.org/system/files/2020-06/ GPEDC_2020-2022_Work_Programme_FINAL_15May.pdf, [accessed on: 19.10.2020].

Helmich H. 1999. "Introduction”, in: Stakeholders Government-GNO Partnership for International Development. Smillie, I., Helmich, H., Randel, J., German, T. (eds)., Earthscan from Routledge.

Horký O. 2011. "Depoliticization, instrumentalization and legitimacy of Czech development cooperation: A case of imposed altruism?" Éthique et économique/Ethics and Economics, Vol. 8, No. 1: 120-132.

Hungary. Ministry of Foreign Affairs and Trade. 2020. "International Development Cooperation Strategy and Strategic Concept for International Humanitarian Aid of Hungary 2014-2020“. https://nefe.kormany.hu/strategy [accessed on: 20.10.2020].

Lewis D., Kanji N. 2009. Non-governmental Organizations and Development. Oxon: Routledge.

Lewis D. 2001. Management of Non-governmental Development Organizations. Oxon: Routledge.

Nanz P., Steffek J. 2004. "Global Governance, Participation and the Public Sphere”. Government and Opposition. Vol. 39, No. 2: 314-335.

OECD. 2020a. "Official development assistance - definition and coverage“. http://www.oecd. org/development/financing-sustainable-development/development-finance-standards/ officialdevelopmentassistancedefinitionandcoverage.htm, [accessed on: 19.10.2020].

OECD. 2020b. "The Busan Partnership for Effective Development Co-operation“. https://www. oecd.org/development/effectiveness/busanpartnership.htm, [accessed on: 19.10.2020].

OECD. 2020c. "Aid for Civil Society Organizations. Statistics based on DAC Members' reporting to the Creditor Reporting System database (CRS), 2017-2018”. http://www.oecd.org/dac/ financing-sustainable-development/development-finance-topics/Aid-for-CSOs-2020.pdf, [accessed on: 19.10.2020].

OECD. 2020d. Development Assistance Committee Members and Civil Society. Paris: OECD Publishing, https://doi.org/10.1787/51eb6df1-en, [accessed on: 20.10.2020].

OECD.Stat. 2020. Development. Credit Reporting System, https://stats.oecd.org/, [accessed on: 2.10.2020]. 
Ott, J. S., Valero, J. N. 2018. "Nongovernmental Organizations and International Nongovernmental Organizations", in: Global Encyclopedia of Public Administration, Public Policy, and Governance, Ali Farazmand A. (ed.). Cham: Springer International Publishing AG.

Smillie I. 1999. "At Sea in a Sieve? Trends and Issues in the Relationship Between Northern NGOs and Northern Governments", in: Stakeholders Government-GNO Partnership for International Development. Smillie, I., Helmich, H., Randel, J., German, T. (eds)., Earthscan from Routledge.

Tortajada C. 2016. "Nongovernmental Organizations and Influence on Global Public Policy". Asia \& Pacific Policy Studies, Vol. 3, No. 2: 266-274.

Treaty on the Functioning of the European Union (consolidated version). OJ C 326, 26.10.2012, p. 47-390.

United Nations. 2020. "UN Charter”. https://www.un.org/en/sections/un-charter/un-charter-fulltext/, [accessed on: 19.10.2020].

United Nations. 2015. "Transforming Our World: The 2030 Agenda for Sustainable Development". https://sustainabledevelopment.un.org/content/documents/21252030\%20Agenda\%20for\%20 Sustainable\%20Development\%20web.pdf, [accessed on: 20.10.2020].

Website of the Republic of Poland. 2020. "Polish Aid. Multiannual Development Cooperation Programme 2016-2020“. https://www.gov.pl/web/polishaid/multiannual-developmentcooperation-programme-2016-2020, [accessed on: 20.10.2020].

Willetts P. 2011. Non-governmental Organizations in World Politics: The construction of Global Governance. Oxon: Routledge. 